\title{
Diagnosis and Management of Pituitary Abscess: A Case Series and Review of the Literature
}

\author{
Hipofiz Abselerinin Tanı ve Tedavisi: Olgu Serisi ve Literatür \\ Değerlendirilmesi
}

\author{
Murat ALTAS ${ }^{1}$, Alpay SEREFHAN ${ }^{2}$, Gokalp SILAV ${ }^{4}$, Ajlan CERCI ${ }^{3}$, Kerim Kenan COSKUN ${ }^{3}$, Ilhan ELMACI ${ }^{4}$ \\ ${ }_{1}^{1}$ Mustafa Kemal University, Faculty of Medicine, Department of Neurosurgery, Antakya, Turkey \\ ${ }^{2}$ Diyarbakır Government Hospital, Department of Neurosurgery, Diyarbakir, Turkey \\ ${ }^{3}$ Goztepe Education and Research Hospital, Department of Neurosurgery, Istanbul, Turkey \\ ${ }^{4}$ Acibadem University, Faculty of Medicine, Department of Neurosurgery, Istanbul, Turkey
}

Corresponding Author: Murat ALTAS / E-mail: draltasmurat@yahoo.com

\begin{abstract}
AIM: Pituitary abscess is a disorder characterized with central nervous system (CNS) infection, mass effect, and endocrine dysfunction. These abscesses generally occur due to hematogenous spread in conditions such as paranasal sinusitis, sepsis, and where the blood brain barrier breaks down. This paper aims to discuss four cases of preoperatively diagnosed pituitary abscess in the light of the literature.

MATERIAL and METHODS: Following detailed clinical and hormonal examinations and imaging tests, 210 cases of pituitary adenoma and other sellar pathologies were operated on at the Neurosurgery clinic of Göztepe Training and Research Hospital.

RESULTS: All the patients showed fever, systemic signs of toxemia and endocrine dysfunction at the time of diagnosis. In these cases, a preoperative diagnosis of the disease was made thanks to characteristic MRI findings. The four cases were operated by the transnasal transsphenoidal approach and histopathological and microbiological studies were performed for surgical specimens.

CONCLUSION: Pituitary abscesses are rare disorders responsible for a high mortality risk. Mortality and morbidity can be reduced by early surgical drainage and appropriate antibiotic treatments. Additionally, these cases should be closely followed-up in terms of pituitary insufficiency, surgical complications and infection.
\end{abstract}

KEYWORDS: Pituitary abscess, MRI imaging, Transsphenoidal surgery, Anti-microbial therapy

öz

AMAÇ: Hipofiz absesi merkezi sinir sistemi (MSS) infeksiyonu, kitle etkisi ve endokrin bozuklukları ile karakterize bir hastalıktır. Bu apseler genellikle kan beyin bariyerinin yıkıldığı hematojen yolla yayılan paranasal sinüzit, sepsis gibi durumulara bağlı oluşur. Bu yazıda literatür ışığında preoperatif tanısı pitüiter apse olan dört olgu tartışılmaktadır.

YÖNTEM ve GEREÇLER: Ayrıntılı klinik, hormonal incelemeleri ve görüntüleme testleri takiben hipofiz adenomu ve diğer sellar patolojileri olan 210 olgu Göztepe Eğitim ve Araştırma Hastanesi Beyin Cerrahisi kliniğinde ameliyat edildi.

BULGULAR: Tüm hastalar tanı sırasında ateş, toksemi ve endokrin bozukluklarının sistemik belirtilerini gösterdi. Bu olgularda, hastalığın preoperatif tanısı karakteristik MRG bulguları sayesinde yapıldı. Bu dört olgu transnazal transsfenoidal yaklaşımla opere edildi ve histopatolojik, mikrobiyolojik çalışmalar cerrahi numunelere yapıldı.

SONUÇ: Hipofiz apseleri yüksek mortalite riskinden sorumlu nadir bir hastalık grubudur. Mortalite ve morbidite erken cerrahi drenaj ve uygun antibiyotik tedavisi ile azaltılabilir. Ayrıca, bu durumlarda hipofizer yetmezlik, cerrahi komplikasyonlar ve enfeksiyon yönünden yakından takip edilmelidir.

ANAHTAR SÖZCÜKLER: Hipofiz absesi, MR görüntüleme, Transsfenoidal cerrahi, Anti-mikrobiyal tedavi

\section{INTRODUCTION}

Pituitary abscesses (PA) are rare but potentially life-threatening lesions. They are potentially responsible for high mortality and morbidity. These lesions account for approximately $0.2-1 \%$ of pituitary lesions $(6,11,12)$. Furthermore, in the last century, a few hundred cases have been reported of which most are sole case reports (12). However, the condition should be considered in the differential diagnosis of sellar masses. These abscesses are generally manifested by meningoencephalitis, mass effect and endocrine dysfunction (2). Presence of accompanying conditions such as cavernous sinus thrombosis increases the mortality. Mortality and morbidity rates can be reduced by early surgical drainage and appropriate antibiotic treatment. Making a correct preoperative diagnosis is stated to be difficult; furthermore, the diagnosis of pituitary abscess was made postoperatively or at necropsy in the majority of cases (12). The typical MRI findings may be important for the diagnosis of the disorder. Here, our aim is to discuss four cases 
of preoperatively diagnosed pituitary abscess in the light of the literature.

\section{METHODS and PATIENTS}

Following detailed clinical and hormonal examinations and imaging tests, 210 cases of pituitary adenoma and other sellar pathologies were operated on at the Neurosurgery clinic of Göztepe Training and Research Hospital between 1995 and 2008. Among these, four patients suffering from sphenoidal sinusitis, pituitary adenoma, and pituitary abscess associated with CNS infection were included in the study. Of these patients, three were female, and the mean age was 35.5 years (ages range 18 to 49 years).

All the patients were diagnosed as pituitary abscess based on the following criteria; (a) a triad of mass effect in the pituitary region, fever and typical MRI findings (b) drainage of PA with or without isolation of organisms, and (c) evidence of acute inflammation and abscess capsule on histopathology. The four cases were treated with surgical operation by the transnasal transsphenoidal approach. The operated three cases were followed up for three years, and the other patient for 18 months. During follow-up, laboratory parameters of the subjects were within normal limits. No recurrence was observed in the control MRIs of these patients.

\section{Case 1}

An 18-year old male patient presented with high fever, mydriasis, and ptosis caused by third cranial nerve involvement. The patient also had sinusitis in the medical history. Vital signs were abnormal including high fever $\left(38.5^{\circ} \mathrm{C}\right)$. On the physical examination, the case had mydriasis and ptosis of the right eye; however, no optic atrophy or papilledema was observed. The laboratory analyses revealed leucocytosis (WBC: 15.600), high sedimentation rate (ESR: 64 $\mathrm{mm} / \mathrm{hr}$ ) and C-reactive protein (CRP) of $16 \mathrm{mg} / \mathrm{L}$. Hormonal profile was as follows: low LH: $2.8(5-15 \mathrm{mlU} / \mathrm{ml})$, low FSH: $3.2(5-15 \mathrm{mlU} / \mathrm{ml})$, low testosterone: $6(9-27 \mathrm{ng} / \mathrm{ml})$, low $\mathrm{fT}_{3}$ : $1.4(1.8-2.1 \mathrm{pg} / \mathrm{ml})$, low $\mathrm{fT}_{4}: 4.5$ (5.5-13.5 ng/dl), prolactin: 28 ( $5-25 \mathrm{ng} / \mathrm{ml}$ ), and low cortisol: $210 \mathrm{nmol} / \mathrm{L}$ (400-550). The pituitary MRI showed a $3 \times 3.5 \times 3 \mathrm{~cm}$ sellar mass. Additionally, postcontrast $\mathrm{T} 1 \mathrm{~A}$ coronal sections showed a lesion referring $\mathrm{PA}$, of which the centre was hypointense consistent with fluid content, with thick capsular contrast involvement, and extending to the lateral wall of cavernous sinus. The lesion compressed the optic chiasm (Figure 1A,B). The case was diagnosed as PA and the abscess was drained by surgery through a transsphenoidal approach. No bacterial growth occurred in the culture of the drained material. Ceftriaxone was administered as an empirical regimen Third cranial nerve functions became normal in the early postoperative period, and hormonal profile was observed to be normal 3 months later. On the T1 A sagittal plan of MRIs obtained during the post-operative period, the pituitary gland was seen as a thin rim, and no residual lesion was observed (Figure $1 \mathrm{C}$ ).

\section{Case 2}

A 43-year old acromegalic female patient presented with the complaints of high fever and headache. On physical examination, the body temperature was $38.7^{\circ} \mathrm{C}$, and tachycardia and hypotension $(90 / 70 \mathrm{mmHg})$ were observed. Additionally leucocytosis and bilateral papilledema were seen. Visual examination revealed bitemporal hemianopsia. CSF analysis showed a leukocyte count higher than $15.000 / \mu \mathrm{L}$ of which 90 percent were neutrophils, which was indicative of meningoencephalitis. The CSF protein level was $400 \mathrm{mg} /$ $\mathrm{dL}$. The laboratory parameters were as follows: ESR and CRP values were $56 \mathrm{~mm} / \mathrm{hr}$ and $13 \mathrm{mg} / \mathrm{L}$, respectively. The levels of ACTH, T3, T4, Cortisol, GH and IGF 1 were lower than normal; yet, the prolactin level was normal. A $2.5 \times 3 \times 3 \mathrm{~cm}$ sellar mass in the hypothalamic-pituitary region was observed on pituitary MRI. In the flair axial section, hyperintense signal changes due to perilesional edema extending to bilateral basal ganglia and the interhemispheric sulcus were noticed (Figure 2A). In postcontrast T1 A coronal plan, an abscess lesion filling the sella with frankly contrasting capsule and an inner part showing fluid intensity was observed. The optic chiasm was contrasted indicating inflammatory change, and was hypointense due to the edema (Figure 2B). The case was operated through a transsphenoidal approach. Methicillinresistant Stapyhlococcus aureus (MRSA) was detected in the culture of drained material; thus, vancomycin therapy was administered. T2 A sagittal imaging obtained in the postoperative period showed that the previously mentioned edema had regressed completely (Figure $2 \mathrm{C}$ ).

\section{Case 3}

A 49-year-old female patient presented with the complaints of acutely developing high fever and headache. She had a history of pansinusitis. Physical examination revealed a body temperature of $38.5^{\circ} \mathrm{C}$, and tachycardia and hypotension were noted. Hemianopsia and pupil stasis were detected on visual examination. Hematological and biochemical parameters were normal on laboratory analyses. As an index of meningoencephalitis, CSF analysis showed a leukocyte count higher than $15.000 / \mu \mathrm{L}$. Furthermore, CSF protein level was $320 \mathrm{mg} /$ $\mathrm{dL}$. The ESR and CRP were found to be $60 \mathrm{~mm} / \mathrm{hr}$ and $17 \mathrm{mg} / \mathrm{L}$, respectively. Regarding hormonal profile, the levels of T3, T4, $\mathrm{TSH}$, cortisol and prolactin were lower than normal. A $3 \times 2.5 \times 3$ $\mathrm{cm}$ sellar mass was detected in the hypothalamic-pituitary region on pituitary $\mathrm{MRI}$, and in post-contrast $\mathrm{T} 1 \mathrm{~A}$ coronal section an abscess lesion with markedly contrasted capsule was observed (Figure 3A). In flair axial section, hyperintense signal changes due to perilesional edema extending to the inferior part of frontal lobe were noticed (Figure 3B). The case was operated through a transsphenoidal approach and abscess drainage was performed. No bacterial growth was observed in the culture of drained material. Ceftriaxone treatment was administered for two weeks (Figure 3C). 

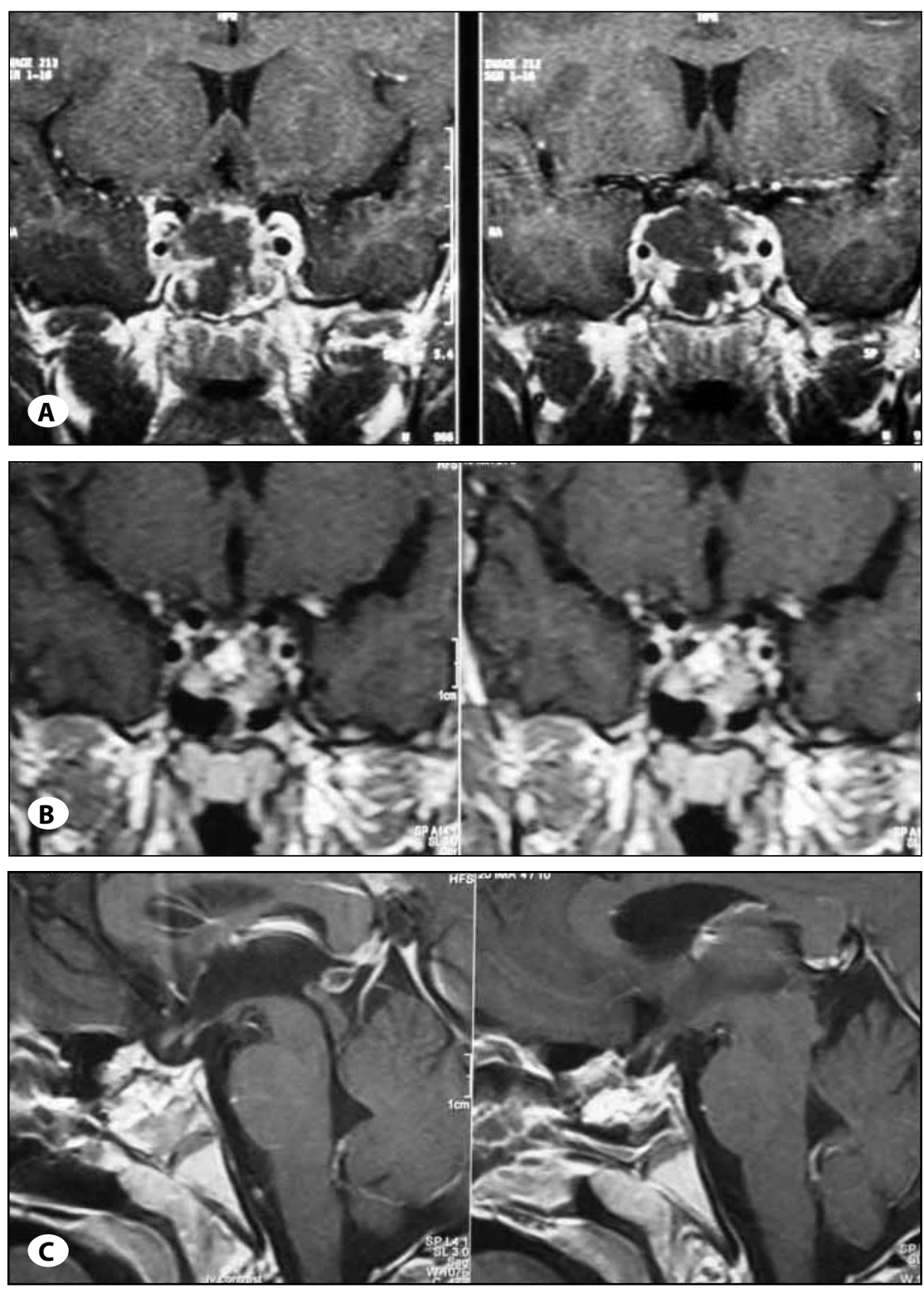

Case 4

A 32-year old female patient presented with severe headache. She had a history of bilateral chronic otitis media and consequent surgical intervention. Systemic and neurological examinations showed normal findings. The pituitary MRI revealed a sellar lesion showing $2 \times 2 \mathrm{~cm}$ of severe contrast enhancement with gadolinium. MRI also presented inflammatory findings of sphenoid sinusitis. Laboratory analyses showed normal biochemical and hormonal parameters. Abscess drainage was performed by transsphenoidal-transnasal approach. Ceftriaxone therapy was given empirically. The patient had no complaints regarding pituitary abscess during 18 months of postoperative follow-up.
Figures 1: A-B) In post-contrast T1 A coronal sections; an abscess showing thick capsular contrast involvement and extending to lateral walls of cavernous sinus with expansion and central part of it observed hypointensely consistent with fluid content. Lesion is in contact with chiasma opticum at the superior. C) During the evaluation of T1 A sagittal imaging; obtained in post-operative period, while pituitary gland is seen as a thin rim, no residual lesion is observed in the sella.

\section{DISCUSSION}

Pituitary abscesses were reported for the first time in 1914 by Simmonds (11). Approximately 250 cases have been reported in the literature since then. Most of the cases have been reported as sole cases. Domingue et al. have reported a series of 7 cases in 1977 (1). Jain et al. have reported only 6 cases among the cases of pituitary surgery including 1000 patients in 1997 (6). Dutta et al. have reported 4 cases with pituitary abscesses out of 1060 cases with pituitary lesions (2). A series of 24 cases among 3500 pituitary surgery patients was reported by Vates et al. (12). Lastly a series, presented by Fuyi et al., comprising 33 cases was the largest in the literature (8).

Pituitary abscess are very rare (0.2-1\%) among all pituitary diseases. There are two types of pituitary abscess; primary and secondary (1). Among these, two-thirds are primary type 
while remaining are secondary type-abscess. A review of the literature revealed that pituitary abscess can be caused either by haematogenous seeding or by direct extension from an adjacent infected tissue as in cases of sphenoid sinusitis, meningitis, contaminated cerebrospinal fluid fistula or cavernous sinus thrombophlebitis (8). On the other hand, a pituitary abscess may develop in a completely normal gland, or in glands that effected by a pre-existing lesion such as an adenoma, a craniopharyngioma or a Rathke's cleft cyst (8, $13,14)$. Among these, the most frequent cause is pansinusitis. In accordance with the literature, three of the presented cases had a history of pansinusitis.

Diabetes insipidus, hypopituitarism and sellar cystic mass with an enhanced rim were reported to be suggestive of pituitary abscess. Furthermore, Fuyi et al. reported that diabetes insipidus was the most common symptom at presentation of their series (8). On the contrary to the literature no diabetes insipidus was diagnosed in the presented series. Clinical symptoms are stated to be nonspecific, in most cases reported in the literature. Classic triad of headache, visual disorders and hormonal dysfunctions can be encountered in all of the cases $(8,14)$. In addition to the classic triad, the presented cases were also diagnosed with meningoencephalitis. There was also pituitary adenoma, which may facilitate the spread of the infection, in two of patients among the presented cases. There have been rare cases of pituitary abscess presenting with acute severe infective manifestations reported in the literature. Fuyi et al. reported only 6 cases that presented with fever and elevated peripheral WBC counts (8). On the contrary to the literature three out four patients were presented with high fever and elevated WBC counts, in this series.

MRI findings indicating cystic or partially cystic pituitary masses with an enhanced rim with postgadolinium administration are nonspecific. Because similar appearance might be seen most sellar lesions, such as Rathke's cleft cysts, cystic craniopharyngiomas, cystic adenoma, and dermoid or epidermoid cyst. Therefore MRI findings are diagnostically valuable when combined with clinical presentation. In this regard, for differential diagnosis of presented cases the authors carefully excluded these entities regardless of the characteristics of the abscess, since abscess might secondary to a sellar lesion as well. Diffusion-weighted imaging has proven be useful in differentiating pituitary abscess from necrotic pituitary tumors. While pituitary abscesses demonstrate high signal intensity with reduction of apparent diffusion coefficient (ADC), necrotic tumors show a hypointensity on DW images and higher ADC values

Pituitary abscess also occurs due to unidentified bacteriemia, septic thrombophlebitis or contaminated cerebrospinal fluid $(3,5,13)$. As causative microorganisms, a wide spectrum of agents including gram (+) cocci (50\% of cases), gram (-) basilli, fungi, amoebae, and yeast had been described in the literature. Most of the cases reported in the literature had stated to be negative in terms of detection of causative organism and positive rates for Gram staining or cultures ranged from $0 \%$ to $64 \%$. $(9,10,13)$ Similarly, no pathogenic organism could be isolated in cultures of three cases in presented series.
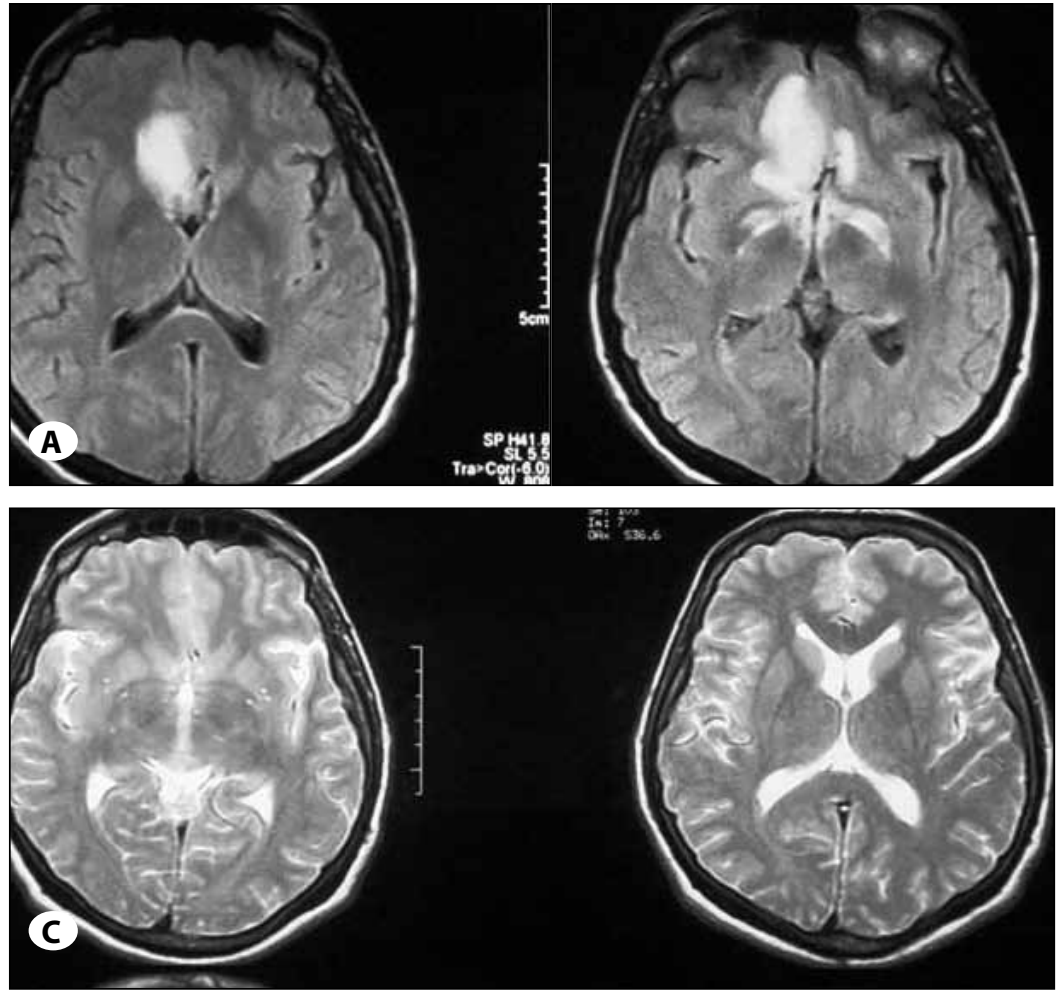

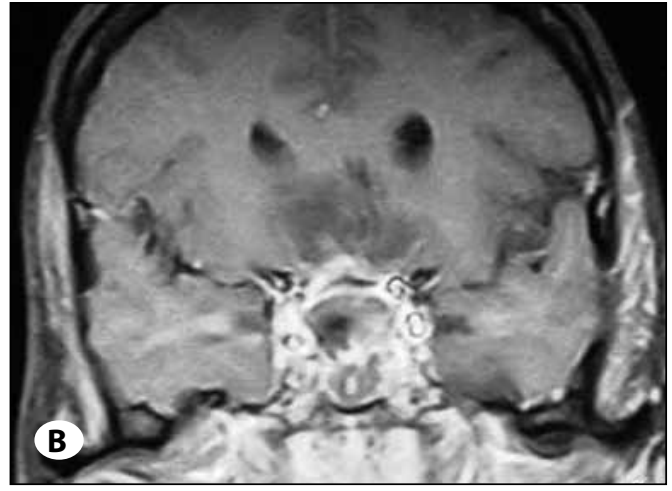

Figures 2: A) In flair axial section; hyperintense signal changes due to perilesional edema extending along with the neighborhood of bilateral basal ganglia and interhemispheric sulcus in the frontal lobe. B) In post-contrast T1 A coronal section; an abscess lesion filling the sella with markedly contrasted capsule and inner part with fluid intensity is observed. There is contrast suggestive inflammatory change in the chiasm in the neighborhood of abscess and hypointensity due to the edema in the neighborhood of it. C) During the evaluation of T2 A sections of MR imaging obtained in the post-operative period, edematous areas are regressed completely. 
Antibiotic therapy should be started as soon as the diagnosis of pituitary abscess is suspected or confirmed during surgery. Broad-spectrum antibiotic therapy should include agents that are effective against Gram-negative, Gram-positive, and anaerobic bacteria. The antibiotic therapy could be used with meningitis-level doses of a third generation cephalosporin until a specific organism is identified in cultures. A review of the literature revealed the complete recovery rate was $60 \%$ while $30 \%$ recovered with hormonal or visual impairment following a combined surgical and medical treatment $(4,7,12)$. Similar to the literature, complete recovery was achieved and no clinical impairment or recurrence of abscess was observed in controls of the presented series.

\section{CONCLUSION}

Pituitary abscesses are rare disorders responsible for high mortality risk. Mortality and morbidity can be reduced by early surgical drainage and appropriate antibiotic treatments. The typical MRI findings are of high importance for the diagnosis of the disorder. The transsphenoidal approach should be preferred in surgery and appropriate antimicrobial therapy should be administered according to the surgical specimen's culture. Additionally, these cases should closely be followedup in terms of pituitary insufficiency, surgical complications and infection.
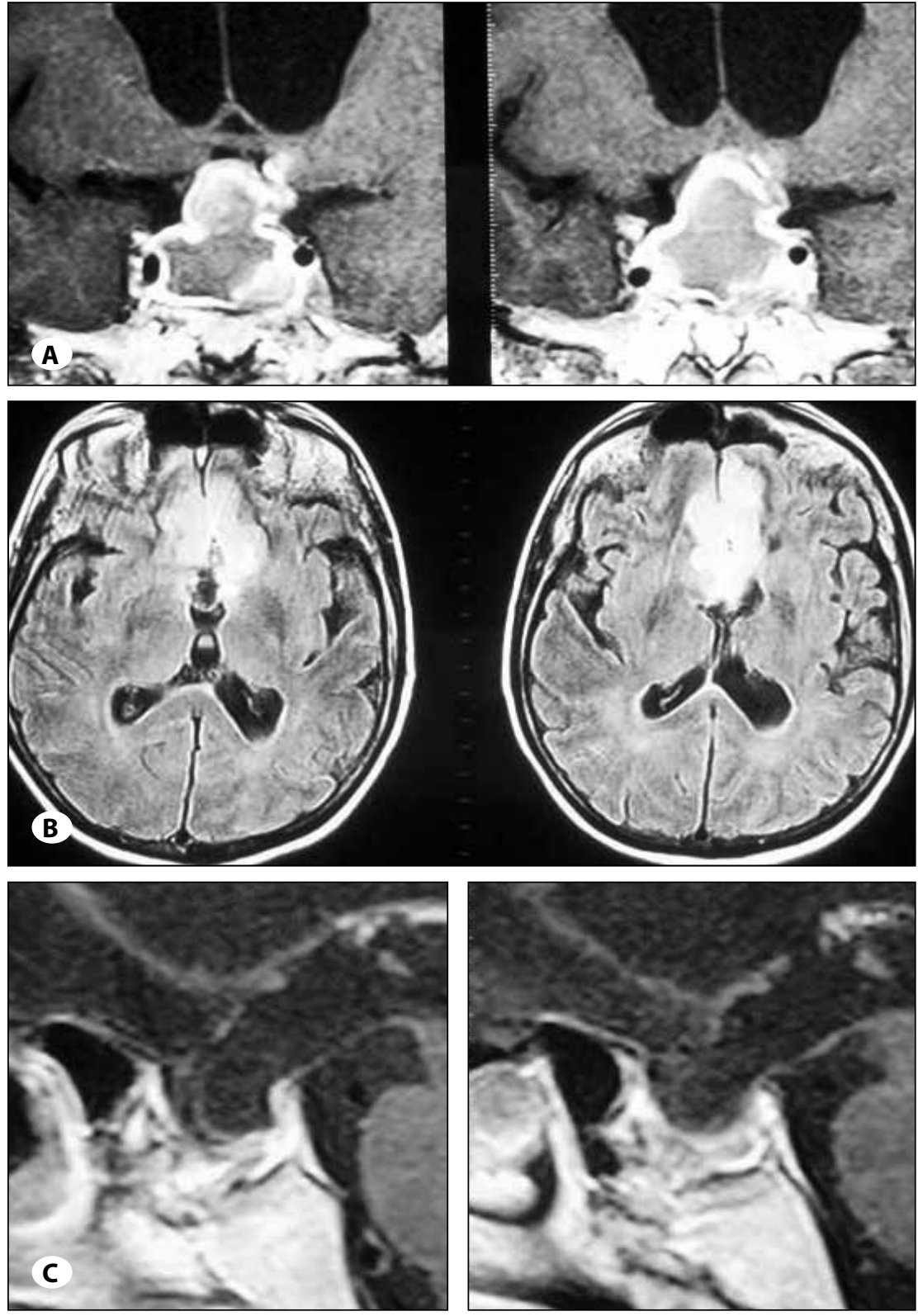

Figures 3: A) In contrast T1 A coronal section; an abscess lesion with markedly contrasted capsule is observed. B) In flair axial section; hyperintense signal changes due to perilesional edema extending to inferior part of frontal lobe is observed. C) In contrasted T1 A sagittal section; obtained in the post-operative period, the normal appearance of sella and pituitary gland and no residual lesion was determined. 


\section{REFERENCES}

1. Domingue JN, Wilson CW: Pituitary abscesses: Report of seven cases and review of the literature. J Neurosurg 46: 601-608,1977

2. Dutta P, Bhansali A, Singh P, Kotwal N, Pathak A, Kumar Y: Pituitary abscess: Report of four cases and review of literature. Pituitary 9: 267-273,2006

3. Grosskopf D, Chamouard JM, Bosquet F, Billet R, Poisson M, Buge A: Pituitary abscess: Study of a case and review of the literature. Neurochirurgie 33: 228-231, 1987

4. Har-El G, Swanson RM, Kent RH: Unusual presentation of a pituitary abscess. Surg Neurol 45: 351-353,1996

5. Jadhav RN, Dahiwadkar HV, Palande DA: Abscess formation in invasive pituitary adenoma: Case report. Neurosurgery 43: 616-619,1998

6. Jain KC, Varma A, Mahapatra AK: Pituitary abscess: A series of six cases. Br J Neurosurg 11: 139-143,1997

7. Lindholm J, Rasmussen P, Korsgaard O: Intrasellar or pituitary abscess. J Neurosurg 38: 616-619, 1973
8. Liu F, Li G, Yao Y, Yang Y, Ma W, Li Y, Chen G, Wang R: Diagnosis and management of pituitary abscess: Experiences from 33 cases. Clin Endocrinol (Oxf) 74(1): 79-88, 2011

9. Sahjpaul RL, Lee $\mathrm{DH}$ : Infratentorial subdural empyema, pituitary abscess and septic cavernous sinus thrombophlebitis secondary to paranasal sinusitis: Case report. Neurosurgery 44: 864-868, 1999

10. Silver HS, Morris LR: Hypopituitarism secondary to cavernous sinus thrombosis. South Med J 76: 642-646, 1983

11. Simmonds M: Zur Pathologie der Ag hypophysis. Verh Dtsch Pathol 117: 208-212, 1914 (in German)

12. Vates GE, Berger MS, Wilson CB: Diagnosis and management of pituitary abscess: A review of twenty-four cases. J Neurosurg 95: 233-241, 2001

13. Wilson CB, Boggan JE: Pituitary abscess. In: Wilkins RH, Rengachary SS (eds), Neurosurgery, London:McGraw-Hill Book Company, 1985:1967-1969

14. Wolansky LJ, Gallagher JD, Heary RF, Malantic GP, Dasmahapatra A, Shaderowfsky PD, Budhwani N: MRI of pituitary abscess: Two cases and review of literature. Neuroradiology 39: 499-503, 1992 